\title{
Influence of the Services Marketing Mix and Place Branding on Tourism Destination Image ${ }^{*}$
}

\author{
Influencia del Marketing Mix de servicios y la marca de lugar en la imagen del \\ destino turístico
}

\author{
Heppy Agustiana Vidyastuti \\ Magister Management Program, STIE Ekuitas, \\ East Java-Indonesia, heppy.agustiana@ekuitas.ac.id
}

\begin{abstract}
How to cite / Cómo citar
Vidyastuti, H. A. (2021). Influence of the Services Marketing Mix and Place Branding on Tourism Destination Image. Revista CEA, v. 7, n. 14, e1646. https://doi.org/10.22430/24223182.1646
\end{abstract}

Received: 28 october 2020

Accepted: 3 february 2021

\begin{abstract}
The aim of this study is to establish if concepts such as the Services Marketing Mix and Place Branding have any influence on Tourism Destination Image. Therefore, it adopted a quantitative crosssectional exploratory methodology. The average annual population of tourists in Garut District, Indonesia, is 231,563; and, using Slovin's formula, a sample size of 100 visitors was calculated. To determine if the items used here to measure the variables of the Services Marketing Mix, Place Branding, and Image were reliable and valid, a Pearson correlation test was conducted. Structural equation modeling was implemented to verify the relationships between the variables. The results indicate that neither the Services Marketing Mix nor Place Branding have any influence on the concept of Tourism Destination Image. Therefore, the strategies designed to improve the image of this tourist destination should be focused on other aspects.
\end{abstract}

Keywords: marketing mix services, place branding, tourism.

JEL Classification: L83, M31.

Highlights

- A more positive or negative destination image cannot be explained by the marketing mix of services.

- It seems that the application of the marketing mix carried out by tourism officers on the South coast of Indonesia is still inadequate. More studies should investigate this aspect.

* This article is derived from the LPPM (Community Service Research Institute) STIE EKUITAS Internal Research Grant Project. 
- Tourism officers should highlight the elements that compose the Santolo Beach brand, such as coral reefs along the coast where small fish live or the big roar of the waves that relaxes the atmosphere, among other elements.

\section{Resumen}

El propósito de este artículo fue el de identificar si conceptos como el Marketing Mix Service y el Place Branding tienen alguna influencia sobre Imagen, para lo cual se utilizó una metodología de tipo cuantitativa, transversal y con alcance exploratorio. Con una población de turistas de 231563 en promedio, por año, y haciendo uso de la fórmula de Slovin, se obtuvo un tamaño de muestra de 100 visitantes. Para determinar si los ítems utilizados para medir las variables de Marketing Mix Service, Place Branding and Imagen eran confiables y válidos, se hizo uso del test de correlación de Pearson (resultados iguales o por encima de 0.3 son aceptables). Para verificar las relaciones entre las variables, se hizo uso de la metodología de ecuaciones estructurales. Los resultados indicaron que ni el Marketing Mix Service ni el Place Branding tienen influencia alguna sobre el concepto de Imagen. Por tanto, las estrategias para impactar positivamente la imagen del destino turístico deben estar orientadas por otras líneas de trabajo.

Palabras clave: Marketing Mix de servicios, marca de lugar, turismo.

Clasificación JEL: L83, M31.

\section{Highlights}

- El Marketing Mix de servicios no explica los altibajos en la imagen de un destino turístico.

- Parece que la forma en que los oficiales de turismo aplican el Marketing Mix en la costa sur de Indonesia es todavía inadecuada. Estudios adicionales deberían investigar este aspecto.

- Los oficiales de turismo deberían resaltar los elementos que componen la marca Santolo Beach, como los arrecifes de coral donde viven peces pequeños o el rugir de las olas que relajan la atmósfera, entre otros.

\section{INTRODUCTION}

Tourism activities in Indonesia have recently begun to grow, develop, and even become a trend and lifestyle in Indonesian society (Sunjayadi, 2018; Chen \& Ting, 2019). As a result, tourism activities are expected to become a mainstay sector able to drive other closely related economic sectors (Mishra et al., 2011; Cheah \& Abdul-Rahim, 2018; Dwi Lestari \& Yuwono, 2020). The Indonesian government, following its development program in the next five years, will focus on the land and maritime infrastructure, energy, food, and tourism sectors. The selection of these five sectors is noteworthy because they have a very significant role in the national development in the short, medium, and long term. Among them, tourism has been determined to be the leading sector because it is predicted to have a positive growth; and can become a medium for inter-sectoral program integration (Weidenfeld, 2018).

Tourism has the strategic role of increasing and supporting national economic development (AduAmpong, 2018). In Indonesia, this sector is a major source of foreign income that employs national 
labor and encourages foreign investment. Bappeda Jabar Humas (2005) mentions that tourism should be strengthened and given special attention, in terms of implementation and development, to create a thriving regional economy in general and especially in Garut District.

Table 1 details the yearly financial contribution of the Indonesian tourism sector to the Gross Domestic Product of Garut District.

Table 1. GDP of Garut District from 2013 to 2015 (in millions of IDR)

Tabla 1. PIB del Distrito de Garut de 2013 a 2015 en millones de rupias indonesias

\begin{tabular}{cccc}
\hline Year & $\begin{array}{c}\text { Income from tourism } \\
\text { services }\end{array}$ & $\begin{array}{c}\text { Total GDP of Garut } \\
\text { District (in millions of IDR) }\end{array}$ & $\begin{array}{c}\text { Contribution to } \\
\text { GDP }\end{array}$ \\
\hline 2013 & $931.318,31$ & $33.687 .510,52$ & $3 \%$ \\
\hline 2014 & $1.017 .077,94$ & $37.084 .186,77$ & $3 \%$ \\
\hline 2015 & $1.139 .908,56$ & $40.681 .251,80$ & $3 \%$ \\
\hline \multicolumn{4}{c}{ Source: Central Bureau of Statistics of Indonesia (2015a). }
\end{tabular}

In the table above, the contribution of tourism to the total GDP of Garut District's is still small, at around 3\%. Therefore, the potential of tourism should be developed so that such contribution increases in the future. Table 2 shows historical data of tourist visits to the West Java Province, Garut District, and Ciamis Distric.

Table 2. Historical data of tourist visits to West Java, Garut District, and Ciamis District (2012-2015)

Tabla 2. Datos históricos de visitas turísticas a Java Occidental, el Distrito de Garit y el Distrito de Ciamis (2012-2015)

\begin{tabular}{|c|c|c|c|c|c|c|c|}
\hline No & Description & $\begin{array}{l}\text { Tourist } \\
\text { type }\end{array}$ & 2012 & 2013 & 2014 & 2015 & CAGR \\
\hline 1 & $\begin{array}{l}\text { West Java } \\
\text { Province }\end{array}$ & $\begin{array}{c}\text { Foreing } \\
\text { tourist } \\
\text { Domestic } \\
\text { tourist }\end{array}$ & $\begin{array}{c}1.905,378 \\
42.758 .063\end{array}$ & $\begin{array}{c}1.794 .401 \\
45.563 .179\end{array}$ & $\begin{array}{c}1.962 .639 \\
47.992 .088\end{array}$ & $\begin{array}{c}2.027 .629 \\
56.334 .706\end{array}$ & $\begin{array}{l}2.09 \% \\
9.63 \%\end{array}$ \\
\hline 2 & Garut & $\begin{array}{c}\text { Foreing } \\
\text { tourist } \\
\text { Domestic } \\
\text { tourist }\end{array}$ & $\begin{array}{c}4.745 \\
1.676 .988\end{array}$ & $\begin{array}{c}5.539 \\
1.962 .703\end{array}$ & $\begin{array}{c}6.334 \\
2.248 .419\end{array}$ & $\begin{array}{c}4.334 \\
1.874 .222\end{array}$ & $\begin{array}{l}-2.97 \% \\
3.78 \%\end{array}$ \\
\hline 3 & Ciamis & $\begin{array}{c}\text { Foreing } \\
\text { tourist } \\
\text { Domestic } \\
\text { tourist }\end{array}$ & $\begin{array}{c}10.074 \\
1.408 .858\end{array}$ & $\begin{array}{c}8.318 \\
1.241 .816\end{array}$ & $\begin{array}{c}6.563 \\
1.074 .775\end{array}$ & $\begin{array}{c}7 \\
169.696\end{array}$ & $\begin{array}{l}-91.14 \% \\
-50.61 \%\end{array}$ \\
\hline
\end{tabular}

Table 2 shows some particularities regarding the number of tourist arrivals in 2015 in each place:

- West Java Province: The Compound Annual Growth Rate (CAGR) of both types of tourism increased: foreign tourism, 2.09\%; and domestic tourism, 9.63\%.

- Garut District: The CAGR of foreign tourists here decreased $2.97 \%$, while that of its domestic counterpart increased $3.78 \%$. The decreasing foreign tourism reflects the mismatch between expectations and reality in the tourist area. Santolo Beach, located in the coastal area of 
Pameungpeuk, is a fairly popular tourist destination among several places in Garut District. Out of a total of 1,874,222 tourists in this district in 2015, 231,563 visited Santolo Beach.

- Ciamis District: The CAGR of both tourist types decrease sharply here because the Ciamis District was affected by the 2004 tsunami.

Table 3 reports the number and type of tourists who visited the West Java Province in 2015.

Table 3. Tourist visits to West Java Province (2012-2015)

Tabla 3. Visitas turísticas a la Provincia de Java Occidental (2012-2015)

\begin{tabular}{|c|c|c|c|c|}
\hline No & Regency / city & Foreing tourist & Domestic tourist & Total \\
\hline$A$ & Regency & & & \\
\hline 1 & Bogor & 228.913 & 4.955 .079 & 5.183 .992 \\
\hline 2 & Sukabumi & 49.985 & 2.031 .979 & 2.081 .964 \\
\hline 3 & Cianjur & 12.100 & 212.095 & 224.195 \\
\hline 4 & Bandung & 867.000 & 5.583 .468 & 6.450 .468 \\
\hline 5 & Garut & 4.334 & 1.874 .220 & 1.878 .554 \\
\hline 6 & Tasikmalaya & 1.362 & 505.570 & 506.932 \\
\hline 7 & Ciamis & & 126.022 & 126.022 \\
\hline 8 & Kuningan & 116 & 1.189 .102 & 1.189 .218 \\
\hline 8 & Cirebon & & 644.224 & 644.224 \\
\hline 10 & Majalengka & 1.500 & 443.001 & 444.501 \\
\hline 11 & Sumedang & 18.637 & 992.315 & 1.010 .952 \\
\hline 12 & Indramayu & & 111.703 & 111.703 \\
\hline 13 & Subang & 748.972 & 3.477 .300 & 4.226 .272 \\
\hline 14 & Purwakarta & 2.782 & 1.957.194 & 1.959 .976 \\
\hline 15 & Karawang & 649 & 4.574 .411 & 4.575 .060 \\
\hline 16 & Bekasi & & 49.740 & 49.740 \\
\hline 17 & Bandung Barat & 278.027 & 1.289 .657 & 1.567 .684 \\
\hline 18 & Pangandaran & 10.344 & 1.824 .367 & 1.834 .711 \\
\hline$B$ & City & & & \\
\hline 19 & Bogor & 13.217 & 5.293 .040 & 5.306 .257 \\
\hline 20 & Subakumi & 3.266 & 82.316 & 85.582 \\
\hline 21 & Bandung & 432.271 & 1.431 .290 & 1.863 .561 \\
\hline 22 & Cirebon & 1.423 & 1.354 .722 & 1.356 .145 \\
\hline 23 & Bekasi & & & \\
\hline 24 & Depok & 7.812 & 1.864 .273 & 1.872 .085 \\
\hline 25 & Cimahi & 339 & 1.968 & 2.307 \\
\hline 26 & Tasikmalaya & 25 & 302.908 & 302.933 \\
\hline \multirow[t]{2}{*}{27} & Banjar & & 50.453 & 50.453 \\
\hline & Total & 2.683 .074 & 42.222 .417 & 44.905 .491 \\
\hline
\end{tabular}

The decrease in the number of both types of tourist visits to Garut District from 2014 to 2015 should be studied in order to understand the marketing mix of tourism services in said district, especially the place branding of Santolo beach, its image, and tourists' decision to visit it. This study aims to analyze the effect of services marketing mix and place branding on the tourism destination image of this place. 


\section{THEORETICAL FRAMEWORK}

\section{Services marketing mix}

According to Zeithaml et al. (2012), "the marketing mix is defined as the elements an organization controls that can be used to satisfy or communicate with customers" (p.23). Furthermore, "the traditional marketing mix is composed of the four Ps: product, place, promotion, and price. [...] In addition to the traditional four Ps, the service marketing mix includes people, physical evidence, and process" (p.23). In turn, Harwiki et al. (2018) claim that innovation is a trigger to survive in the global market; without innovation an enterprise quickly becomes hackneyed. Mukherjee and Shivani (2016) argue that "the model represents service marketing mix influence on certain selected dimensions of brand equity, namely, brand image(s) and perceived service quality and thereby on brand equity." Chandra (2015) asserts that "the result is showing that intensity of marketing activities is not significantly impacting brand equity through brand awareness." Additionally, only price and store image have a significant effect on brand equity through brand image, whereas intensity of marketing activities and price deals do not (Peter et al., 2018).

\section{Place branding}

According to Blain et al. (2005), place branding are the marketing activities:

1. That support the creation of a name, symbol, logo, word mark or other graphic that both identifies and differentiates a destination; 2 . That convey the promise of a memorable travel experience that is uniquely associated with the destination; and 3 . That serve to consolidate and reinforce the recollection of pleasurable memories of the destination experience, all with the intent purpose of creating an image that influences consumers' decisions to visit the destination. (p.331)

Govers and Go (2009) posit that "Place branding is not just about communicating, but also about actual investment in local products, tourism services, infrastructure, education, sports, health care and cultural heritage." (p.15). Furthermore, "Place branding refers to branding and building brand equity in relation to national, regional and/or local (or city) identity." Suyana and Senoh (as cited in Avraham \& Ketter, 2008) suggests that "the branding of a place can be divided into three categories: brand spirit, brand resources, and brand personality." (p.15). Balakrishnan et al. (2011) report that the concept of destination branding can be complex because it includes corporate branding and elements such as products and services. Govers and Go (2009) locate city branding in a hexagon that consists of presence, place, potential, pulse, people, and prerequisites (p.3).

\section{Tourism Destination Image}

Aksoy and Kiyci (2011) define image as "the thing that is designed in mind and wanted to be realized, dream, impression" (p. 479). Sometimes these cues have unintended as well as intended symbolic value (p. 13). Kotler and Keller (2012) argue that "corporate image is the sum of people's perception [...] created through all sense: sight, sound, smell, touch, taste and feeling experienced through product usage product, customer service, the commercial environment and corporate 
communication. "Store image can be defined as a particular type of feedback from those in given market regarding the credibility of the identity claims that the organization makes" (Cretu \& Brodie, 2007). Other authors like Ranjbarian et al., (2012); Majtán and Frianová, (2011) have claimed that "In today's competitive environment, many companies need to project a strong and positive reputation two their stakeholders, namely the employees, consumers, investors and the public."

\section{METHOD}

This study applied a quantitative method supported by an explanatory survey focused on customer perception of the services marketing mix, place branding, and image, where the intangible variables were marketing mix services and place branding and the tangible variable was image. The data sources were primary and secondary. The primary data, obtained from tourist respondents in the field, are concerned with the services marketing mix, place branding, and image. Secondary data convey supporting information that complements research data. Primary data are obtained from questionnaires, interviews, and observations, while secondary data are obtained from a government institute of Indonesia known as Badan Pusat Statistik (BPS) and from books and related documents.

The survey was conducted by a team of researchers at Santolo beach in southern Garut. The instrument used to collect the data was a questionnaire administered to visitors of said beach. The design of the research instrument was based on three research variables: services marketing mix, place branding, and image. The questionnaire was composed of closed-ended questions that were answered using a Likert scale from 1 to 5 . In this paper, validity and reliability were supported if the Pearson correlation coefficient was greater than or equal to $0.30(r \geq 0.3)$.

Structural Equation Modeling (SEM), i.e., a data analysis technique, and LISREL 9.2 Student software were used here to analyze the problems mentioned above. SEM models are statistical techniques that can be employed to simultaneously test a series of relatively complex relationships. Complex relationships can be established between one or several dependent variables with one or several independent variables. The steps followed in this study to conduct the SEM are explained in Figure 1.

This study implemented simple random probability sampling (Pardjono et al., 2015), a sampling technique where all the individuals in the population, individually or in groups, have the same probability of being selected for the sample.

The survey was conducted on Santolo Beach, a tourist destination in southern Garut. Simple random sampling was applied, and Slovin's formula resulted in a sample size of 100 respondents (out of 231,563 tourists). As expressed in Umar (2008), Slovin's formula is $n=N /(1+N e 2)$, where $n=$ sample size/number of respondents; $\mathrm{N}$, population size; and e, maximum tolerable error rate $(10 \%$ in this case). 


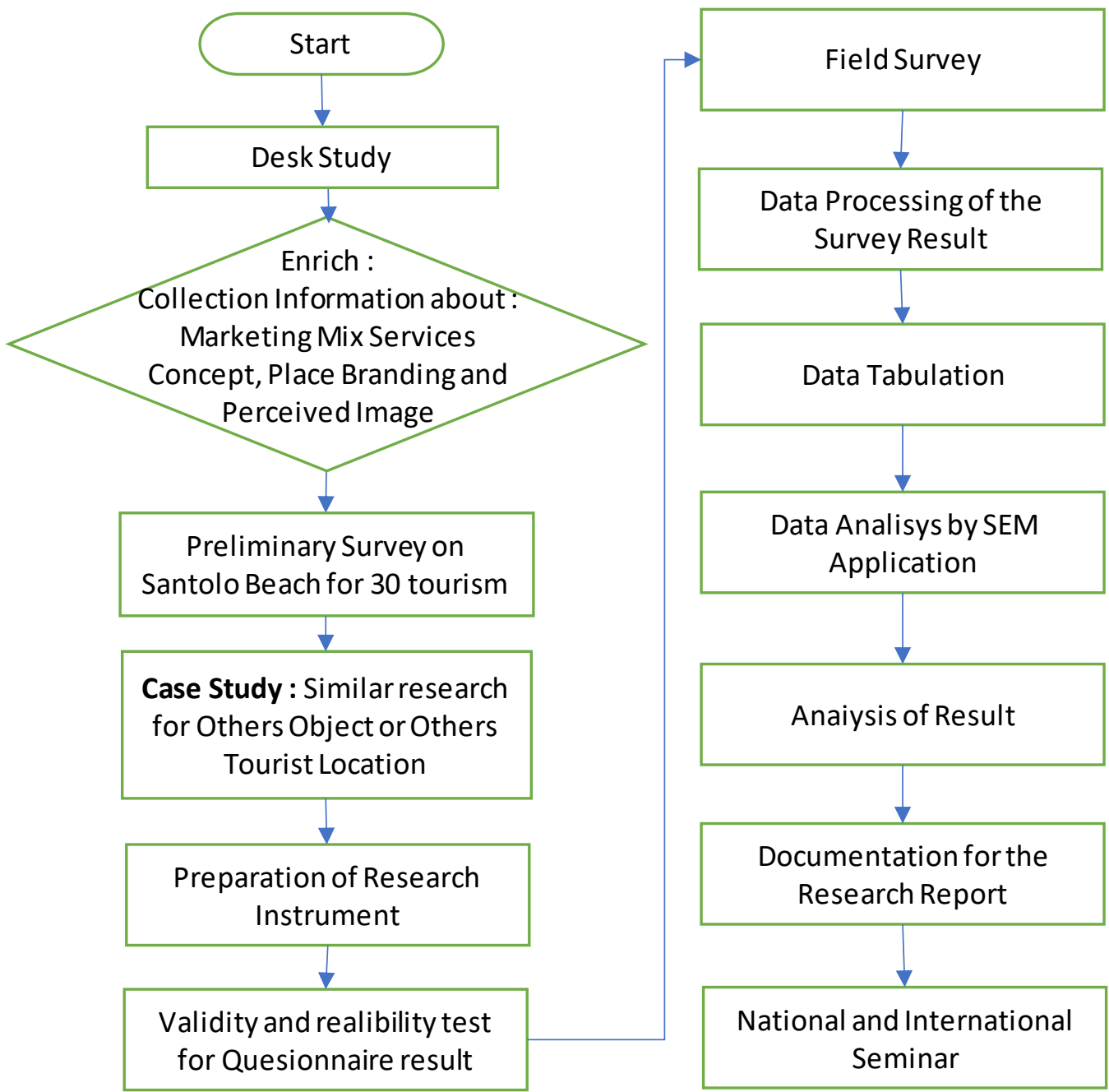

Figure 1. Steps followed in this study

Figura 1. Pasos de este estudio Source: Created by the authors.

\section{RESULTS}

Validity and reliability

According to Pardjono et al., (2010), validity tests are employed in research to measure how well a research instrument that has been developed can measure a construct. The requirement to pass the validity test in this study is a Pearson correlation coefficient greater than or equal to $0.30(r \geq 0.3)$; therefore, variables with values $<0.30$ were not supported. Table 4 presents the validity test results of each variable (i.e., Marketing Mix, Place Branding, and Destination Image). 
Table 4. Validity test results of independent variables in the Marketing Mix (Pearson correlation test) Table 4. Resultados del test de validez de las variables independientes en el Marketing Mix

\begin{tabular}{|c|c|c|c|c|}
\hline Variable & Sub-variable & r count & Condition $r$ & Conclusion \\
\hline \multirow{9}{*}{$\begin{array}{c}\text { Services } \\
\text { Marketing } \\
\text { Mix }\end{array}$} & \multirow{2}{*}{ Service (X1) } & $.578^{* *}$ & $>0.30$ & Valid \\
\hline & & $.654^{* *}$ & $>0.30$ & Valid \\
\hline & Price $(X 2)$ & $.708^{* *}$ & $>0.30$ & Valid \\
\hline & Place (X3) & $.463^{* *}$ & $>0.30$ & Valid \\
\hline & Promotion (X4) & $.467^{* *}$ & $>0.30$ & Valid \\
\hline & People (X5) & $.469^{* *}$ & $>0.30$ & Valid \\
\hline & \multirow{2}{*}{ Physical Evidence (X6) } & $.783^{* *}$ & $>0.30$ & Valid \\
\hline & & $.760^{* *}$ & $>0.30$ & Valid \\
\hline & Process (X7) & $.467^{* *}$ & $>0.30$ & Valid \\
\hline \multirow{4}{*}{$\begin{array}{c}\text { Place } \\
\text { Branding }\end{array}$} & Presence (X8) & $870^{* *}$ & $>0.30$ & Valid \\
\hline & Place (X9) & $.875^{* *}$ & $>0.30$ & Valid \\
\hline & Potential (X10) & $.913^{* *}$ & $>0.30$ & Valid \\
\hline & Pulse (X11) & $.847^{* *}$ & $>0.30$ & Valid \\
\hline \multirow{4}{*}{$\begin{array}{l}\text { Destination } \\
\text { Image }\end{array}$} & Personality (X12) & $875^{* *}$ & $>0.30$ & Valid \\
\hline & Reputation (X13) & $.847^{* *}$ & $>0.30$ & Valid \\
\hline & Value (X14) & $.913^{* *}$ & $>0.30$ & Valid \\
\hline & Destination Identity (X15) & $.846^{* *}$ & $>0.30$ & Valid \\
\hline
\end{tabular}

Note: ${ }^{* *}$ Correlation is significant at the 0.01 level (2-tailed)

Source: Created by the authors.

In Figure 2, the coefficient of the influence of the Services Marketing Mix (named BauranPJ) on Tourism Destination Image (named CitraP) is 0.298 (approximately 0.30), and that of Place Branding (named Fbrandin) on Tourism Destination Image is 0.356 (approximately 0.36 ).

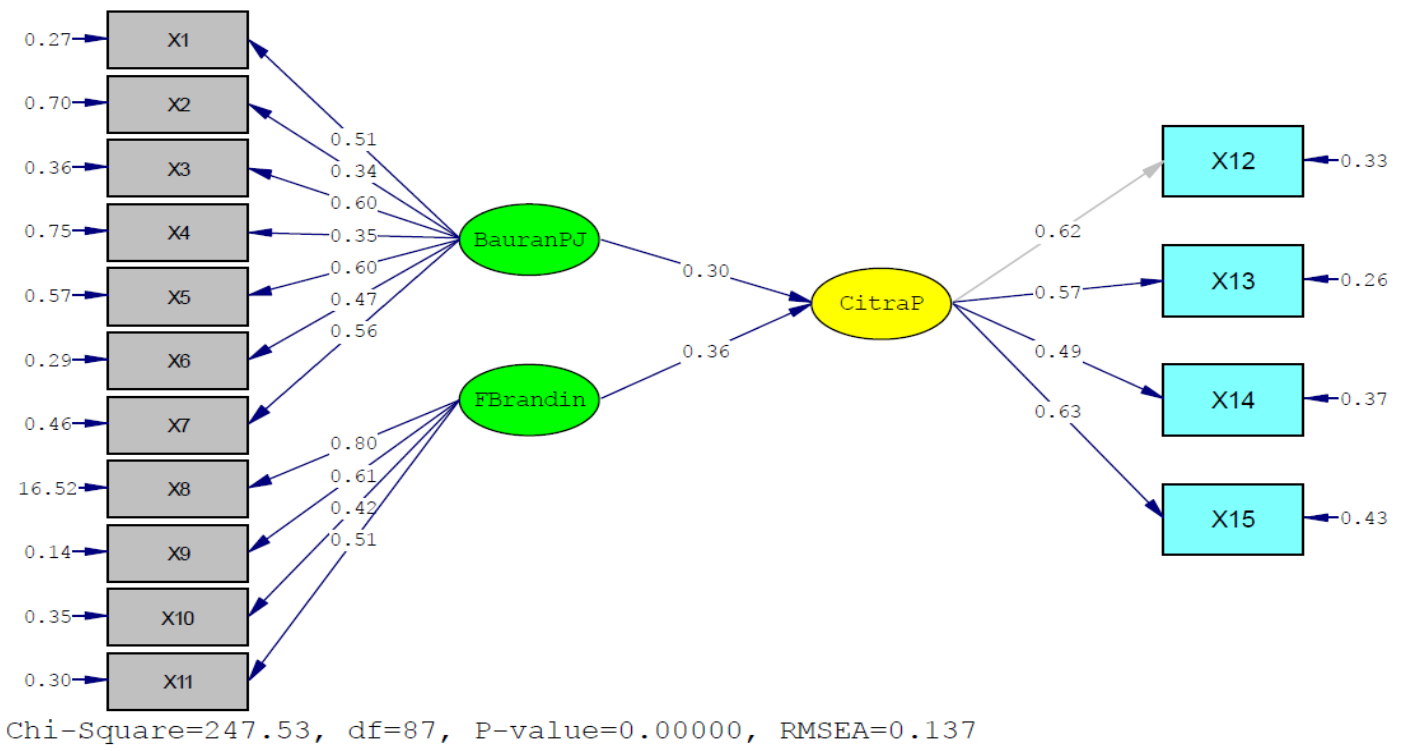

Figure 2. Influence of Services Marketing Mix and Place Branding on Tourism Destination Image. CitraP: Tourism Destination Image, BauranPJ: Services Marketing Mix, and Fbrandin: Place Branding

Figura 2. Influencia del Marketing Mix para servicios y marca de lugar en la imagen del destino turístico. CitraP: imagen del destino turístico, BauranPJ: Marketing Mix para servicios y Fbrandin: marca de lugar Source: Created by the authors. 
Table 5 presents the hypotheses tested here to verify the relationships between variables.

Table 5. Hypothesis testing to verify relationships between variables

Table 5. Pruebas de hipótesis para verificar relaciones entre variables

\begin{tabular}{lccccc}
\hline Variable relationships & $\begin{array}{c}\text { Estimated } \\
\text { coefficient }\end{array}$ & $\begin{array}{c}\text { Standard } \\
\text { error }\end{array}$ & T-value & Decision \\
\hline BauranPJ $\longrightarrow$ CitraP & 0.298 & 0.218 & 1.367 & Not supported. \\
\hline Fbrandin $\longrightarrow$ CitraP & 0.356 & 0.215 & 1.656 & Not supported. \\
\hline & $\begin{array}{r}\text { Note: } \\
\text { So* } p<0.001, * * p<0.01, * p<0.05\end{array}$ \\
& $\begin{array}{r}\text { Source } \text { Created by the authors. } \\
\end{array}$
\end{tabular}

The hypothesis of the influence of BauranPJ on CitraP was tested applying the following procedure:

Hypothesis Test 1:

$H_{0}: \gamma_{21}=0 \quad$ The Services Marketing Mix has no effect on Image.

$\mathrm{H}_{1}: \gamma_{21} \neq 0 \quad$ Place Branding influences Image.

As a result, we obtained the following test statistics:

Ho is rejected if $t_{1} \geq t$-table.

$$
t_{1}=\frac{\gamma_{11}}{s e\left(\gamma_{11}\right)}=\frac{0.298}{0.218}=1.367
$$

Ho is not rejected if $t_{1}<t$-table.

The same procedure was carried out to testing the influence of Fbrandin on CitraP:

Hypothesis Test 2:

$H_{0}: \gamma_{22}=0 \quad$ Place Branding has no effect of on Image.

$\mathrm{H}_{1}: \gamma_{22} \neq 0 \quad$ Place Branding influences Image.

As a result, we obtained the following test statistics:

$$
t_{2}=\frac{\gamma_{22}}{s e\left(\gamma_{22}\right)}=\frac{0.356}{0.215}=1.656
$$

Ho is rejected if $t_{2} \geq t$-table.

$\mathrm{Ho}$ is not rejected if $\mathrm{t}_{2}<\mathrm{t}$-table.

The t- value of Hypothesis 1 was 1.367, and that of Hypothesis 2 was 1.656. As both values are below the t-table $=1.98$ (with an alpha of $5 \%$ ), the sampled data fails to reject the null hypothesis; thus, neither of the two effects are supported. 


\section{DISCUSSION}

This study is in line with Kavaratzis and Hatch (2013) in that image and place branding should be analyzed in order to promote tourism. Other studies have supported a positive relationship between place branding and destination image. McCreary et al. (2020) claim that a component of place branding is the visual image of the place. According to Garay (2019), in the current globalized context we live, local brands undoubtedly play a crucial role in the formation of the image of tourist destinations. Gertner (2019) refers to the influence of place branding on destination image through cultural appropriation but criticizes the fact that indigenous rituals and traditions are exploited to draw in tourists. She also calls on those in charge of place branding to listen to and talk with leaders of the communities involved in order to have their approval in terms of the dissemination of their cultural traditions. This was the origin of this paper, which analyzed the influence of place branding on the tourism destination image of Santolo Beach in Garut, Indonesia.

The services marketing mix has also been highlighted in the literature because it has a positive influence on tourism destination image. According to $\mathrm{Hu}$ (2009), the marketing mix strategy is very important in maintaining the image of products. The results obtained by Garay (2019) indicate that destination management organizations should be oriented toward the creation of strategies that project the image of tourism destinations based on the promotion of certain products, even if it means paying less attention to already popular products.

Although the literature has reported a positive orientation and influence of constructs such as services marketing mix and place branding on tourism destination image (Boisen et al., 2018), this study did not find evidence in the same line. The statistical results here indicate that the services marketing mix has no influence on image. Therefore, a more positive or negative image cannot be explained by the services marketing mix currently being implemented by the tourism organization. This could be due to the fact that the marketing mix is not adequately applied by tourism officers to Santolo Beach in Garut. Therefore, tourists may have different perceptions, which has an impact on their satisfaction and dissatisfaction. This lack of association between place branding and destination imagen may exist because not enough attention has been paid to the elements that compose the brand. In this particular case, Santolo Beach offers a number of coral reefs along the coast where small fish live and the big roar of the waves that calms the atmosphere, among other elements.

\section{CONCLUSIONS}

A total of 100 visitors to Santolo Beach in Garut participated in this survey. Considering the data collected and the data analysis conducted using Structural Equation Modeling, it can be concluded that, in this case, the concepts of the services marketing mix and place branding have no influence whatsoever on the concept of image. Hence, the strategies designed to improve the image of this this tourist destination should be focused on other aspects.

The literature review in this paper suggests that further studies should analyze the place image and branding of other tourist destinations in order to lay solid foundations to design strategies to promote them. Therefore, they should should differentiate the type of tourist destination (beach, mountain, 
and city, among others) and establish the components that make them different to better manage their image.

Further studies should compare tourist destinations in developed countries and emerging markets to understand how this influences the perception of place image and branding. Additionally, statistical samples should be robust and heterogeneous in order to produce more accurate models that contribute to strengthen the tourism sector.

\section{CONFLICTS OF INTEREST}

The author declares no conflict of financial, professional, or personal interests that may inappropriately influence the results that were obtained or the interpretations that are proposed here.

\section{REFERENCES}

Adu-Ampong, E. A. (2018). Tourism and national economic development planning in Ghana, 19642014. International Development Planning Review, v. 40, n. 1, 75-95. https://doi.org/10.3828/idpr.2018.2

Aksoy, R.; Kiyci, S. (2011). A Destination Image As a Type of Image and Measuring Destination Image in Tourism (Amasara Case). European Journal of Social Sciences, v. 20, n. 3, 478-488. URL

Avraham, E.; Ketter, E. (2008). Media Strategies for Marketing Places in Crisis Improving the Image of Cities, Countries and Tourist Destinations. Elsevier.

Bappeda Jabar Humas. (2005). RPJPD Kabupaten Garut Tahun 2005-2025. URL

Balakrishnan, M.; Nekhili, R.; Lewis, C. (2011). Destination Brand Components. International Journal of Culture, Tourism and Hospitality Research, v. 5, n. 1, 4-25. https://doi.org/10.1108/17506181111111726

Blain, C.; Levy, S. E.; Brent Ritchie, J. R. (2005). Destination Branding: Insights and Practices from Destination Management Organizations. Journal of Travel Research, v. 43, n. 4, 328-338. https://doi.org/10.1177/0047287505274646

Boisen, M.; Terlouw, K.; Groote, P.; Couwenberg, O. (2018). Reframing place promotion, place marketing, and place branding-moving beyond conceptual confusion. Cities, v. 80, 4-11. https://doi.org/10.1016/j.cities.2017.08.021

Central Bureau of Statistics of Indonesia. (2015a). GDP of Garut District from 2013 to 2015 (in millions of IDR). $\underline{U R L}$

Central Bureau of Statistics of Indonesia. (2015b). Garut Dalam Angka 2010. URL 
Chandra, I. R. (2015). The Impact of Marketing Mix Elements toward Brand equity throught Brand Awareness and Brand Image as Mediators in Bakery Industry in Indonesia. iBuss Management, v. 3, n. 2, 341-350. URL

Cheah, C. F.; Abdul-Rahim, A. S. (2018). Relationship between Health Care and Tourism Sectors to Economic Growth: The Case of Malaysia, Singapore and Thailand. Pertanika Journal of Social Science and Humanities, v. 26, n. 2, 1203-1213. URL

Chen, W. F.; Ting, T. Y. (2019). Contesting shopping tourism: Neoliberal consumption scapes and conflicts in host societies. Tourism Culture \& Communication, v. 19, n. 2, 155-160. https://doi.org/10.3727/109830419X15536971539434

Cretu, A. E.; Brodie, R. J. (2007). The influence of brand image and company reputation where manufacturers market to small firms: A customer value perspective. Industrial Marketing Management, v. 36, n. 2, 230-240. https://doi.org/10.1016/j.indmarman.2005.08.013

Dwi Lestari, E.; Yuwono, M. K. (2020). The Effect of Family-Work and Work-Family Conflict on Call Center Workers' Emotional Exhaustion With Person-Job Fit as Antecedent. Revista CEA, v. 6, n. 12, 69-85. https://doi.org/10.22430/24223182.1616

Garay, L. (2019). \#Visitspain. Breaking down affective and cognitive attributes in the social media construction of the tourist destination image. Tourism Management Perspectives, v. 32, 100560. https://doi.org/10.1016/j.tmp.2019.100560

Gertner, R. K. (2019). The impact of cultural appropriation on destination image, tourism, and hospitality. Thunderbird International Business Review, v. 61, n. 6, 873-877. https://doi.org/10.1002/tie.22068

Govers, R.; Go, F. (2009). Place Branding Glocal, Virtual and Physical Identities, Constructed, Imagined and Experienced. Palgrave Macmillan.

Harwiki, W.; Choiron, A.; Hartini, S. (2018). Batik Creative Industry: Creativity, Innovation and Competitiveness to Encounter Global Market. Journal of Business and Finance in Emerging Markets, v. 1, n. 2, 189-196. https://doi.org/10.32770/jbfem.vol1189-196

Hu, Y. J. (2009). Service Quality as Mediator of the Relationship between Marketing Mix Strategy and Customer Loyalty: The Case of Retailing Stores in Taiwan. International Journal of Organizational Innovation, v. 2, n. 2, 282-293. URL

Kavaratzis, M.; Hatch, M. J. (2013). The dynamic of place brands: An identity-based approach to place branding theory. Marketing Theory, v. 13, n. 1, 69-86. https://doi.org/10.1177/1470593112467268

Kotler, P.; Keller, K. L. (2012). Marketing Management (2 ed.). Prentice Hall Europe. 
Majtán, S.; Frianová, V. (2011). Marketingová komunikácia podnikov cestovného ruchu - tvorba a optimalizácia komunikačného mixu. Ekonomický časopis, v. 59, n. 2, 178-193. URL

McCreary, A.; Seekamp, E.; Davenport, M.; Smith, J. W. (2020). Exploring qualitative applications of social media data for place-based assessments in destination planning. Current Issues in Tourism, v. 23, n. 1, 82-98. https://doi.org/10.1080/13683500.2019.1571023

Mishra, P. K.; Rout, H. B.; Mohapatra, S. S. (2011). Causality between tourism and economic growth: Empirical evidence from India. European Journal of Social Sciences, v. 18, n. 4, 518-527. URL

Mukherjee, S.; Shivani, S. (2016). Marketing Mix Influence on Service Brand Equity and Its Dimensions. Vision: The Journal of Business Perspective, v. 20, n. 1, 9-23. https://doi.org/10.1177/0972262916628936

Pardjono, P.; Sugiyono, S.; Budiyono, A. (2015). Developing a model of competency and expertise certification tests for vocational high school students. REID (Research and Evaluation in Education), v. 1, n. 2, 129-145. https://doi.org/10.21831/reid.v1i2.6517

Peter, O. R.; Oundo, B. H.; Lydiah, A. (2018). The Effect of Store Image and Price on Store Brand Equity: Evidence from Supermarkets in Kenya. IOSR Journal of Business and Management, v. 20, n. 10, 15-23. https://doi.org/10.9790/487X-2010021523

Ranjbarian, B.; Sanayei, A.; Rashid Kaboli, M.; Hadadian, A. (2012). An Analysis of Brand Image, Perceived Quality, Customer Satisfaction and Re-Purchase Intention in Iranian Department Stores. International Journal of Business and Management, v. 7, n. 6, 40-48. https://doi.org/10.5539/ijbm.v7n6p40

Sunjayadi, R. A. (2018). Dari Turisme ke Pariwisata: Melacak Jejak Istilah Turisme di Indonesia. Melancong: Jurnal Perjalanan Wisata, Destinasi, dan Hospitalitas, v. 1, n. 1, 1-23. URL

Umar, H. (2008). Desain Penelitian MSDM dan Perilaku Karyawan: Paradigma Positivistik dan Berbasis Pemecahan Masalah, Edisi I, Cetakan Pertama. Raja Grafindo Persada.

Weidenfeld, A. (2018). Tourism Diversification and Its Implications for Smart Specialisation. Sustainability, v. 10, n. 2, 319. https://doi.org/10.3390/su10020319

Zeithaml, V. A.; Bitner, M. J.; Gremler, D. (2012). Services Marketing: Integrating Customer Focus Across the Firm (7th ed.). Mc Graw-Hill. 